\title{
CALAKMUL AS A CENTRAL PLACE: ISOTOPIC INSIGHTS ON URBAN MAYA MOBILITY AND DIET DURING THE FIRST MILLENNIUM AD
}

\author{
T. Douglas Price, Vera Tiesler, William J. Folan, and Robert H. Tykot
}

\begin{abstract}
Isotopic investigations of human burials from excavations of the Autonomous University of Campeche (CIHS) at the prehispanic Maya capital of Calakmul in southeastern Mexico, near the border with Guatemala, include determination of radiocarbon dates; carbon and nitrogen isotope ratios in collagen; and strontium, carbon, and oxygen isotope ratios in tooth enamel. A total of 22 human and 5 faunal samples analyzed for strontium isotopes reveal a narrow range of variation in values, pointing to the likely local origin of over two-thirds of the central population of Calakmul, including two of its rulers. Carbon and nitrogen data confirm a typical Classic Maya diet at the site and identify a diet high in meat consumption for one dynastic individual. Interpreted jointly, the isotopic information offers new perspectives on the provenience and lifestyles of the residents of Calakmul, including a potential place of origin for the royal occupant of chamber tomb Burial VII-1.
\end{abstract}

Las investigaciones isotópicas de los entierros humanos recuperados en el centro regional Maya prehispánico de Calakmul, Mexico, durante las excavaciones a cargo del Centro de Investigaciones Históricas y Sociales de la Universidad Autónoma de Campeche incluyen fechas de radiocarbono y proporciones de isótopos de carbono y nitrógeno en colágeno, así como de isótopos de estroncio, carbono y oxígeno en esmalte dental. Se analizaron 22 muestras de restos humanos y 5 especímenes faunísticos. El análisis de los valores de isótopos de estroncio reveló un estrecho rango de variación, indicando el origen local de más de dos tercios de los residentes centrales de Calakmul. Los datos de carbono y nitrógeno confirman una dieta típica para una población maya al estar fuertemente basada en carbohidratos de plantas C4 (como lo son maíz y frijol). Solo un individuo, correspondiente a un dinasta, difiere de este patrón. En este caso, los valores indican una dieta alta en consumo de carne. La comparación regional de nuestros resultados proporciona nueva información sobre la procedencia y los estilos de vida de las poblaciones residentes de Calakmul, y sobre el posible lugar de origen de un dinasta que ocupó la cámara funeraria del entierro VII-1.

$\mathrm{T}$ The ancient Maya city of Calakmul was the capital of one of the most powerful Classic Maya kingdoms. At the heart of what became the Snake Kingdom, Calakmul played a pivotal role in the regional politics of the Maya Lowlands during the first millennium AD. Nestled in a riverless, endorheic basin and distant from reliable, year-round sources of potable water while also lacking consistent rainfall, Calakmul relied successfully on complex hydraulic management to feed its residents with adequate amounts of staple crops (Gunn and Folan 2000; Stuart and Stuart 2008). This ancient city also relied on extensive trade to obtain additional food and raw materials.

The Calakmul elite, characterized by shifts in spheres of power and far-reaching regional

\footnotetext{
T. Douglas Price Laboratory for Archaeological Chemistry, University of Wisconsin-Madison, 1180 Observatory Drive, Madison, Wisconsin, 53706, USA (tdprice@wisc.edu)

Vera Tiesler $\square$ Facultad de Ciencias Antropológicas, Universidad Autonóma de Yucatán, km 1.00 carretera Mérida-Tizimín, Cholul, C.P. 97305 Mérida, Mexico

William J. Folan $\square$ Centro de Investigaciones Históricas y Sociales, Universidad Autónoma de Campeche, Av. Agustín Melgar s/n entre Juan de la Barrera y Calle 20, San Francisco de Campeche, C.P. 24030, Campeche, México

Robert H. Tykot Department of Anthropology, University of South Florida, 4202 E. Fowler Ave., SOC107, Tampa, Florida 33620, USA
} 
networks, remain poorly understood. Epigraphers have associated the shifts with movements of linguistic/ethnic groups across the Maya lowlands (Folan et al. 2010; Josserand 2007; Lacadena and Wichman 2002, 2005). The stylistic and chemical signature of the majority of local ceramics analyzed by Domínguez Carrasco (2008) and Domínguez Carrasco and others (2015) show that they were produced at Calakmul, with copious exchange between Calakmul, Becan, El Mirador, Uaxactun, Tikal, and Barton Ramie during the Early Classic, and between Becan, Calakmul, and El Mirador during the Late Classic.

The location and far-flung political and economic interaction of Calakmul raise questions about the mobility of its residents, along with their food sources and dietary habits. Here we describe and discuss the isotopic evidence from human burials excavated by the Autonomous University of Campeche (CIHS) from 1983 to 1994, including radiocarbon dates; carbon and nitrogen isotope ratios in collagen; and strontium, carbon, and oxygen isotope ratios in tooth enamel. These data provide novel information on chronology, water sources, potential places of origin, and child and adult diets of the core population of Calakmul, including two of its rulers.

\section{Calakmul in Perspective}

Calakmul lies in the southeastern part of the modern state of Campeche, Mexico, some $35 \mathrm{~km}$ north of the Guatemalan border (Figure 1). Decades of systematic survey and excavations at Calakmul, led by William Folan (Autonomous University of Campeche) and Ramón Carrasco (Instituto Nacional de Antropología e Historia), have provided detailed information on the urban settlement patterns, architecture, dynastic sequence, artifacts, and buried human remains (Carrasco 2012; Folan et al. 2008; Martin and Grube 2008). Although recent decipherments of Maya epigraphy have provided a narrative for the dynastic history and regional interaction (summarized in Martin and Grube 2008) of Calakmul, bioarchaeological investigations have put a human face on its urban dwellers (summarized in Tiesler 2012).
Calakmul dates to the Preclassic and Classic periods (600 BC to AD 900). During the Late Classic (AD 550-830), Calakmul administered a major regional state encompassing an area on the order of $8,000 \mathrm{~km}^{2}$ (Folan et al. 1995, 2013; Marcus 1992, 2003; Martin and Grube 2008). Calakmul was likely one of the largest cities in the Maya region, with a population estimated at approximately 50,000. With some 6,500 structures, the site is huge and covered an area of more than $30 \mathrm{~km}^{2}$ in the middle of the northern Peten rain forest, now protected as a biosphere. Calakmul itself was recently declared a World Heritage site.

Here we report the results of the isotopic investigation of the human remains recovered by the Autonomous University of Campeche in the core of Calakmul (Figure 2). The mortuary treatment documented among these burials includes simple interments, chamber tombs, and sacrificial deposits. These contexts come mostly from excavated structures on and around the Central Plaza, along with Burials Ch-8-1 and Ch$8-2$, which were recovered from isolated contexts surrounding the epicenter. A considerable part of this skeletal series (5 of 12 mortuary contexts with status assignment; Table 1) corresponds to richly attired elite tombs that were likely occupied by royalty. At the other extreme are the individuals recovered from probable sacrificial contexts or midden deposits ( 3 out of 12 mortuary contexts with status assignment; Table 1). This burial population is by no means representative of the whole population of the city, and even less so of the elite of the Snake Kingdom.

The Central Plaza is a large open area that was presumably used for religious, civic, and military activities (Folan et al. 1995, 2001a). Structure II, its southern platform, was the most voluminous at Calakmul and is one of the largest in the Maya area (Figure 3). Several of the burials sampled for this study came from here: Burials II-1, II-2, II-3, II-5, II-6, and II-7 from Structure II; Burials IIH-1, IIH-2 from Structure IIH; Burials IIB-1, and IIB-2 from Structure IIB; and two unusual deposits $(n=12)$. Taken together, these crypt-, grave-, and refuse contexts span the Classic period. They contained the human remains of eight adults, three juveniles, and one child. Abundant funerary accouterments were 
Table 1. Sampled Burials, Demographic Data and Isotope Measurements.

\begin{tabular}{|c|c|c|c|c|c|c|c|c|c|c|c|c|}
\hline LabNo. & Burial No. & Age & Sex & Status & Period & Tooth & ${ }^{87} \mathrm{Sr} /{ }^{86} \mathrm{Sr}$ & $\delta^{13} \mathrm{C}_{\mathrm{ap}}$ & $\delta^{18} \mathrm{O}_{\mathrm{ap}}$ & $\delta^{13} \mathrm{C}_{\mathrm{col}}$ & $\delta^{15} \mathrm{~N}_{\mathrm{col}}$ & $\Delta_{\text {Ap-col }}$ \\
\hline $\mathrm{F} 2421$ & E. II-1 (6) & A & M & $\mathrm{S}$ & $\mathrm{LC}$ & M1 & 0.7079 & & & & & \\
\hline $\mathrm{F} 2342$ & E. II-2 (7) & I & - & unk & EC & LLM1 & 0.7083 & & & & & \\
\hline F2346 & E. II-3 (10) & A & M & unk & $\mathrm{TC}$ & LRM1 & 0.7078 & -3.9 & -1.3 & & & \\
\hline F2424 & B. II-5 (12) & A & $\mathrm{F}$ & $\mathrm{L}$ & $\mathrm{C}$ & & 0.7078 & & & & & \\
\hline $\mathrm{F} 2350$ & E. II-6 (16) & A & $\mathrm{F}$ & unk & $\mathrm{LC}$ & LRM1 & 0.7085 & -3.9 & -2.8 & -10.2 & 10.5 & 6.31 \\
\hline F2351 & E. II-7 (1 & $\mathrm{JU}$ & - & $\mathrm{L}$ & LC & LRM1 & 0.7078 & -8.6 & -1.5 & -14.5 & 13.1 & 5.9 \\
\hline F2352 & E. IIH-1 (1 & A & M & $\mathrm{H}$ & LC & LRM1 & 0.7078 & & & & & \\
\hline $\mathrm{F} 2353$ & E. IIH-2 (2 & A & $\mathrm{M}$ & M & $\mathrm{LC}$ & LLM1 & 0.7078 & & & & & \\
\hline F2354 & E. IIB-1 & $\mathrm{JU}$ & $\mathrm{M}$ & $\mathrm{M}$ & $\mathrm{LC}$ & ULM1 & 0.7078 & & & & & \\
\hline F2355 & E. IIB-2 (2 & A & M & unk & $\mathrm{TC}$ & URM1 & 0.7079 & -7.5 & -1.7 & -9.6 & 12.7 & 2.08 \\
\hline F2418 & E. II-Stela 114 (23) & A & $\mathrm{F}$ ? & $\mathrm{S}$ & $\mathrm{LC}$ & & 0.7079 & & & & & \\
\hline & E. II & A & - & PD & $\mathrm{TC}$ & & 0.7078 & & & & & \\
\hline F2339 & E. III-1 (2) & A & M & & $\mathrm{TC}$ & LRM1 & 0.7080 & -6.6 & -1 & -11.6 & 11.6 & 5.01 \\
\hline F2340 & E. III-2 & A & $\mathrm{F}$ & unk & $\mathrm{TC}$ & RM1 & 0.7079 & & & & & \\
\hline F2341 & E. III-3 (4) & A & M & unk & EC & LM1 & 0.7078 & & & & & \\
\hline & E. II & A & M & $\mathrm{H}$ & $\mathrm{C}$ & URM1 & 0.7078 & & & & & \\
\hline F234 & E. III-6 & A & M & unk & $\mathrm{C}$ & URM1 & 0.70791 & -6.3 & -1.5 & -12.7 & 11.6 & 6.41 \\
\hline F2348 & E. III-7 & A & M & $\mathrm{L}$ & $\mathrm{LC}$ & LLM1 & 0.70795 & & & & & \\
\hline F2349 & E. III-8 (15) & A & $\mathrm{F}$ & $\mathrm{L}$ & $\mathrm{LC}$ & LRM1 & 0.70784 & & & & & \\
\hline F2338 & E. VII-1 (1) & A & M & $\mathrm{H}$ & $\mathrm{LC}$ & URM1 & 0.70778 & & & -19.7 & & \\
\hline F2343 & E. CH 1-1 (8-1) & A & - & unk & $\mathrm{TC}$ & LM1 & 0.70788 & & -0.1 & -7.8 & 10.2 & 4.95 \\
\hline $\mathrm{F} 2344$ & E. $\mathrm{CH} 1-2(8-2)$ & $\mathrm{JU}$ & $\mathrm{M}$ & unk & $\mathrm{TC}$ & RM1 & 0.70788 & -2.8 & -0.7 & -8.4 & 9.5 & 5.58 \\
\hline
\end{tabular}

Tooth: $\mathrm{U}=$ upper, $\mathrm{L}=$ Lower, $\mathrm{R}=$ right, $\mathrm{L}=$ left, $\mathrm{M} 1=$ first molar. Age: $\mathrm{A}=$ adult, JU: juvenile, $\mathrm{I}=$ infant. Sex: $\mathrm{M}=$ male, $\mathrm{F}=$ female. Status: $\mathrm{H}=$ high, $\mathrm{M}=$ middle, $\mathrm{L}=$ lower, $\mathrm{S}=$ sacrifice, $\mathrm{PD}=$ special deposit. Period: $\mathrm{L}=$ late, $\mathrm{T}=$ terminal, $\mathrm{E}=$ early, $\mathrm{C}=$ Classic, unk = unknown, $\mathrm{CH}=$ chultun. Burial number indicates structure in Roman number and the burial number assigned by the project. Sequenced burial numbers assigned at the Bioarchaeology Lab (UADY) appear in parentheses.

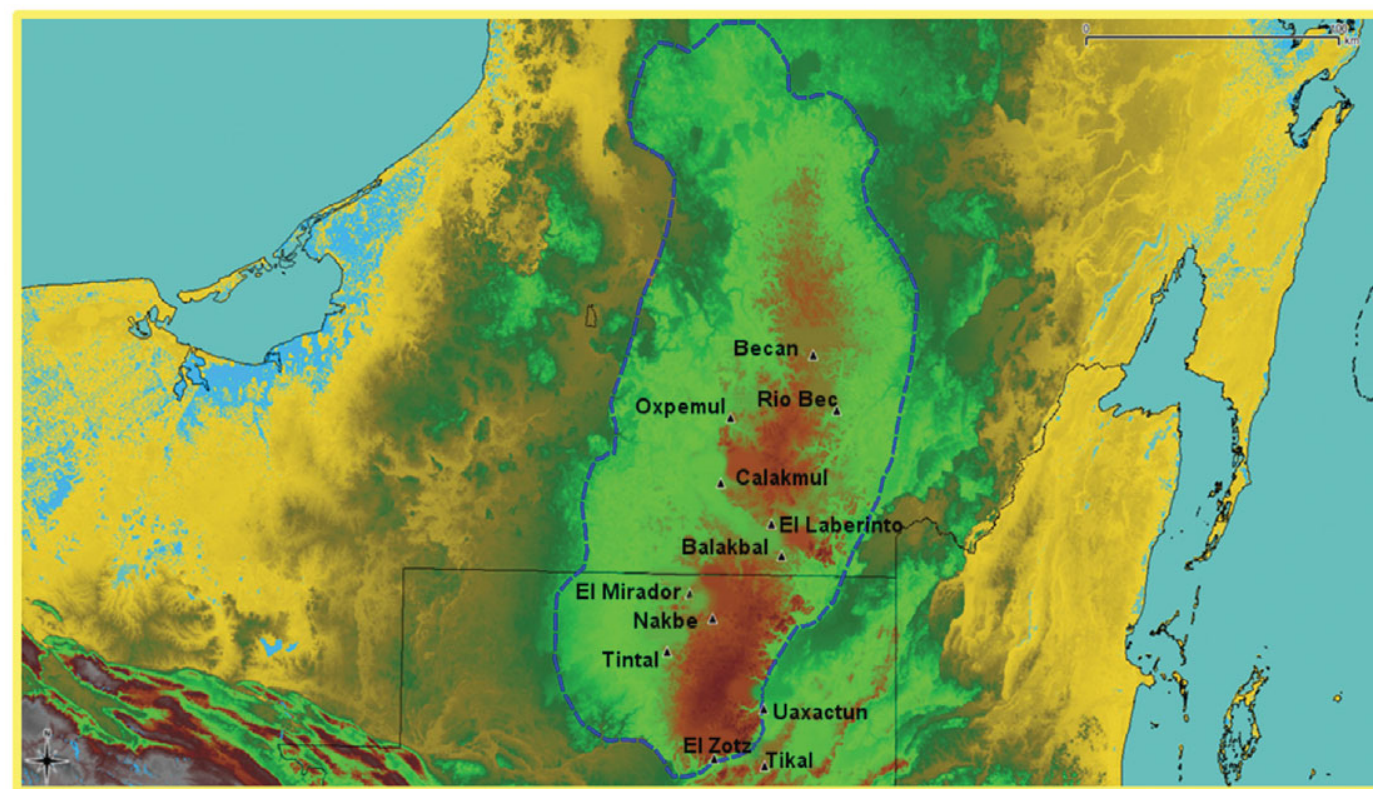

Figure 1. Regional map of the northern Peten, southern Yucatan, and Gulf Coast of Mexico, northern Guatemala, and northern Belize. The colors reflect elevation. The dashed line marks the endorheic basin of the Peten and southern Yucatan Peninsula. The locations of major archaeological sites are marked. (Color online) 


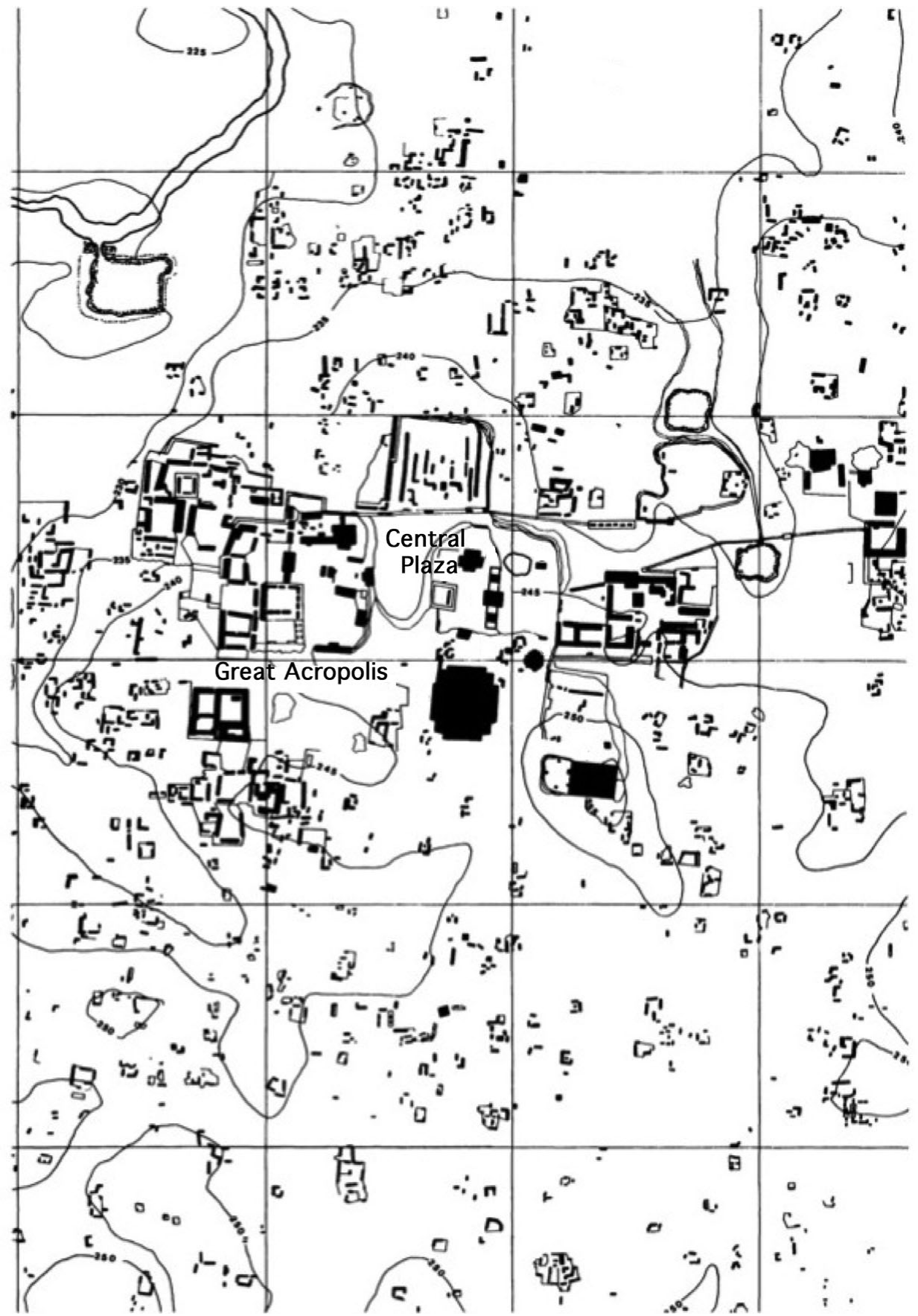

Figure 2. Plan of the core of Calakmul (after Folan et al. 2001a). North is up, and each grid unit is $500 \mathrm{~m}$ on a side.

recovered from Structure IIH, where two vaulted tombs were excavated (Folan and Morales López 1996). One of the individuals included here was an adult who had been cremated in a fleshed state below Stela 114. In all likelihood, this individual had been sacrificed as part of the ritual ceremony involved in resetting an Early Classic Stela ("IIStela") at the onset of the Late Classic period (Folan et al. 1995; Medina Martin and Sánchez Vargas 2007). Structure VII closes the Central 

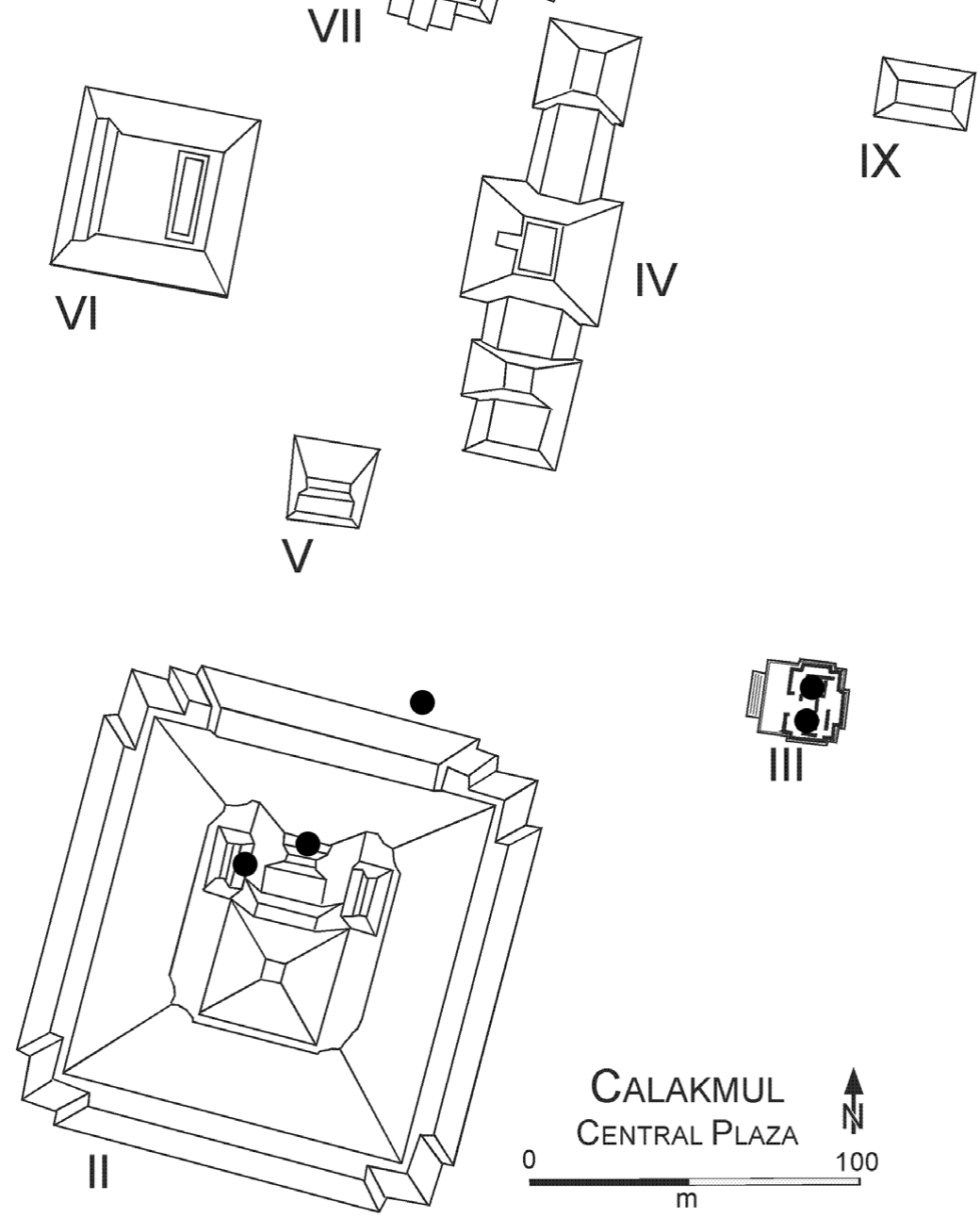

Figure 3. The Central Plaza at Calakmul with Structures II-VIII. Burial locations shown as black dots (inset, Figure 2).

Plaza in its north. From here we document the tomb of a ruler, also unidentified. Dated to circa $\mathrm{AD} 750$, the large, stuccoed chamber tomb contained the remains of a male ruler who died during his fourth or fifth decade of life (Tiesler 1999; Tiesler et al. 2013; see also Lagunas 1985). The regal accoutrements include a jaguar pelt, a life-sized jadeite mosaic portrait mask, four large jadeite earplugs, a large $i k$ '-shaped jade thorax plaque, and two cheek or lip plugs carved with glyphs.
To the east of the Central Plaza lies Structure III, also called the Lundell Palace, which once served as a central elite residence. Tomb III5 stands out among the rest of the funerary contexts of Structure III; this spacious, elaborate Early Classic funerary chamber was constructed beneath Room 6 in the center of Structure III and most likely contained the remains of an early, as yet unnamed, ruler of Calakmul. The contents of the tomb included a mat and a variety of textile fragments (Tiesler et al. 2013; Figure 4). A 


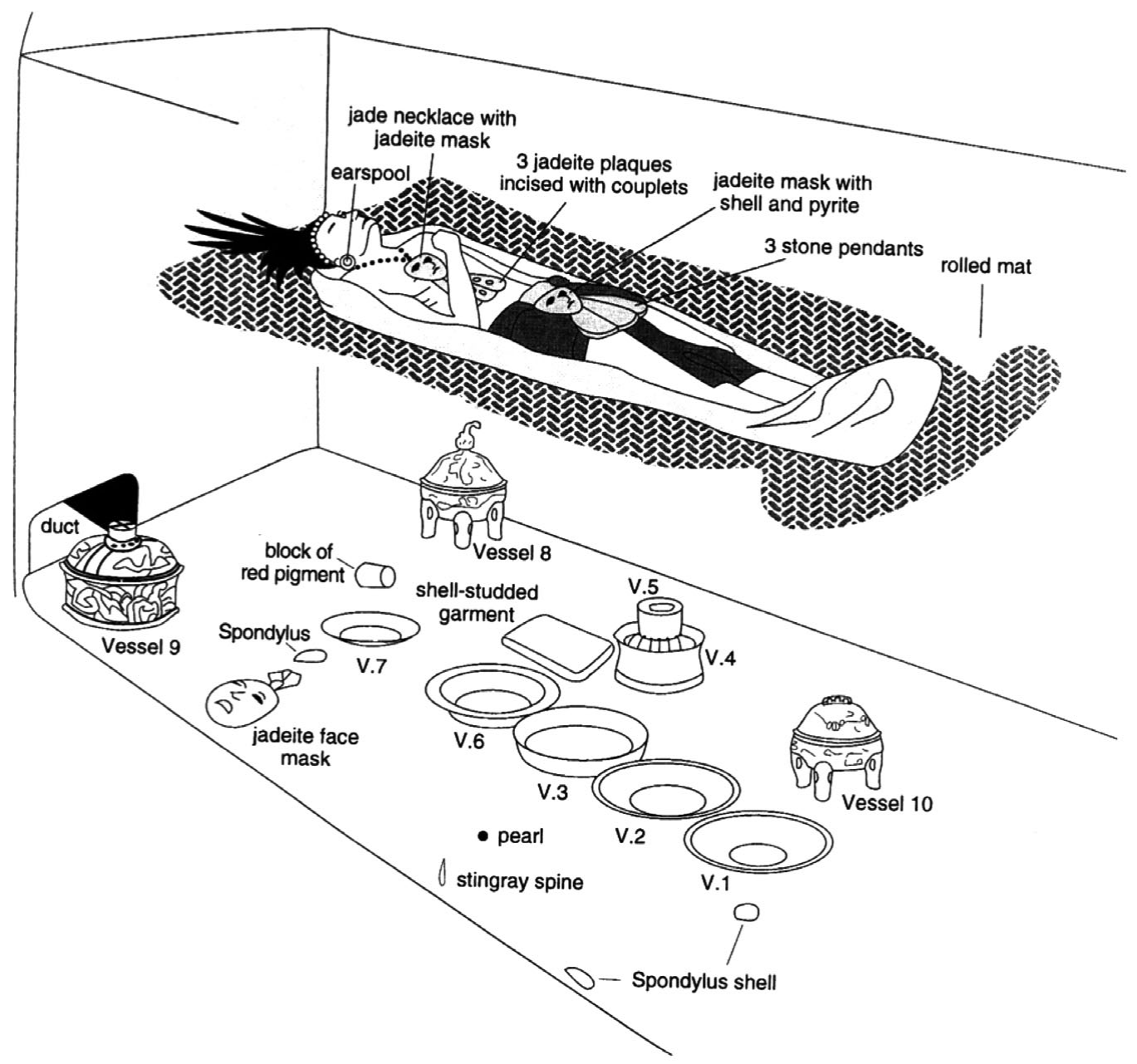

Figure 4. Artist's reconstruction of Tomb III-5, Structure III, at Calakmul (Sophia Pincemín Deliberos 1994).

cloth adorned with hundreds of shells, arranged to form distinct designs, was placed near the deceased, along with other shells carved to represent human skulls. Three pairs of jade earplugs, a jade ring, 32 jade beads, 3 incised jade plaques, 8,252 shell beads, a stingray spine, 5 more elaborate ceramic vessels, and a fragment of a stucco vessel were also in the tomb. Among the offerings, 3 jade mosaic masks stand out: one next to the face, another lying on the chest, and the third at one side of the waist of the deceased (García Vierna 2004; Martínez de Campo Lanz 2010).

The collective study of the above burial series provides information on the residential population, including social status. To charac- terize social status, we scored burial wealth and architecture in each primary context, using a polythetic set of attributes described in detail elsewhere (Price et al. 2012:34-35; Tiesler 1999). For each individual, we also report their chronological association, sex, age at death, and living conditions, following standard procedures and classifications as described in Buikstra and Ubelaker (1994) and Loth and Henneberg (1996). We classified the dental work in the form of filing and inlays according to the taxonomy established originally by Romero (1958; Tiesler 2000). In the documentation of artificial head modifications, we followed criteria adapted by Romano (1965) and Tiesler (2014). 
Table 2. Radiocarbon Dates and $\delta^{13} \mathrm{C}_{\mathrm{col}}$ Values for Two Samples from Calakmul. $\mathrm{LC}=$ Late Classic.

\begin{tabular}{llllclc}
\hline Burial & Lab No. & Years bp & cal BC 2-sigma & $\%$ & $\delta^{13} \mathrm{C}_{\text {col }}$ & Period \\
\hline IIH-2 (20) & AA74497 & $1441 \pm 60$ & AD 529-681 & 93.6 & -10.5 & LC \\
VII-1 (1) & AA74499 & $1233 \pm 52$ & AD 667-894 & 99.3 & -19.7 & LC \\
\hline
\end{tabular}

Table Legend: Burial number integrates designation of structure (Roman numbering) and the burial number assigned by the project. Sequential burial numbers assigned at the Bioarchaeology Lab at UAY in Merida appear in parentheses.

\section{Isotopic Studies}

For the purposes of this research, we used several isotopic ratios obtained from bones and teeth. Radiocarbon has been used to obtain dates on bone collagen. In the following pages we first discuss the principles of these methods and known variations in these isotope ratios in the Maya region. The extraction and evaluation procedures for this study are described in detail in published work elsewhere (Price et al. 2012). In addition to the stable carbon isotopes, radiocarbon ratios were obtained from two diaphyseal samples from Calakmul to obtain direct chronological dates for the analyzed individuals. The calibration of ${ }^{14} \mathrm{C}$ dates, provided in Table 2, converts radiocarbon years to calendar years.

\section{Carbon and Nitrogen Isotopes}

Nitrogen isotope ratios can reveal the importance of meat in the diet, the role of freshwater fish, and the trophic level of human diets. In this study, carbon isotope ratios were also measured in tooth enamel apatite $\left(\delta^{13} \mathrm{C}_{\mathrm{en}}\right)$. Tooth enamel, and the carbonate and phosphate minerals where carbon is bound, forms during childhood. Thus, while bone collagen provides a record of adult diet, tooth enamel is a record of the diet of early childhood.

\section{Strontium Isotopes}

We have measured hundreds of strontium isotope samples from the Maya region, summarized in Figure 5. We obtained specific local baseline data for Calakmul from two archaeological samples of white-tailed deer and three modern samples from snails from the site itself. These values are presented in Table 3 and define a rather tight local range for Calakmul. The five faunal samples have a mean and standard deviation of $0.70776 \pm$
0.00002 , with a range of 0.70775 to 0.70780 . Maya centers more than $50 \mathrm{~km}$ distant, including Becan and Balamku to the north and Tikal, El Mirador, and Piedras Negras to the south, show average values of 0.708 or greater.

\section{Oxygen Isotopes}

In bones and teeth, isotope variation in $\delta^{18} \mathrm{O}$ due to physiological factors (e.g., perspiration, metabolic rate, urine) averages out, with variation among local populations less than $2 \%$ (White et al. 2002). Oxygen isotopes have been employed in a number of studies in Mesoamerica in recent years (e.g., Spence et al. 2004; White et al. 1998, 2000, 2001, 2002, 2004; Wright and Schwarcz 1998). In addition to the published data, the Laboratory for Archaeological Chemistry has been measuring oxygen isotope ratios in tooth enamel for some time. A summary of these data is presented in Figure 6 for some of the major prehispanic settlements in Mesoamerica. These data are reported as $\delta^{18} \mathrm{O}_{\mathrm{ap}}$ (PDB) in enamel.

\section{Results}

\section{Carbon and Nitrogen Isotopes}

Radiocarbon dates were obtained from two bone samples. Burial IIH-2(20) dated to the sixth or seventh century, and Burial VII-1 dated to the late seventh to the ninth century. Information regarding these determinations is provided in Table 2. Both ranges roughly confirm chronology estimates from ceramic wares associated with the burial contexts. What was surprising was the difference in $\delta^{13} \mathrm{C}_{\mathrm{col}}$ between the two samples. Burial IIH-2, an adult elite male, has a very high $\delta^{13} \mathrm{C}_{\mathrm{col}}$ ratio, typical of maize eaters in the Maya region (e.g., Tykot 2002). In contrast, 


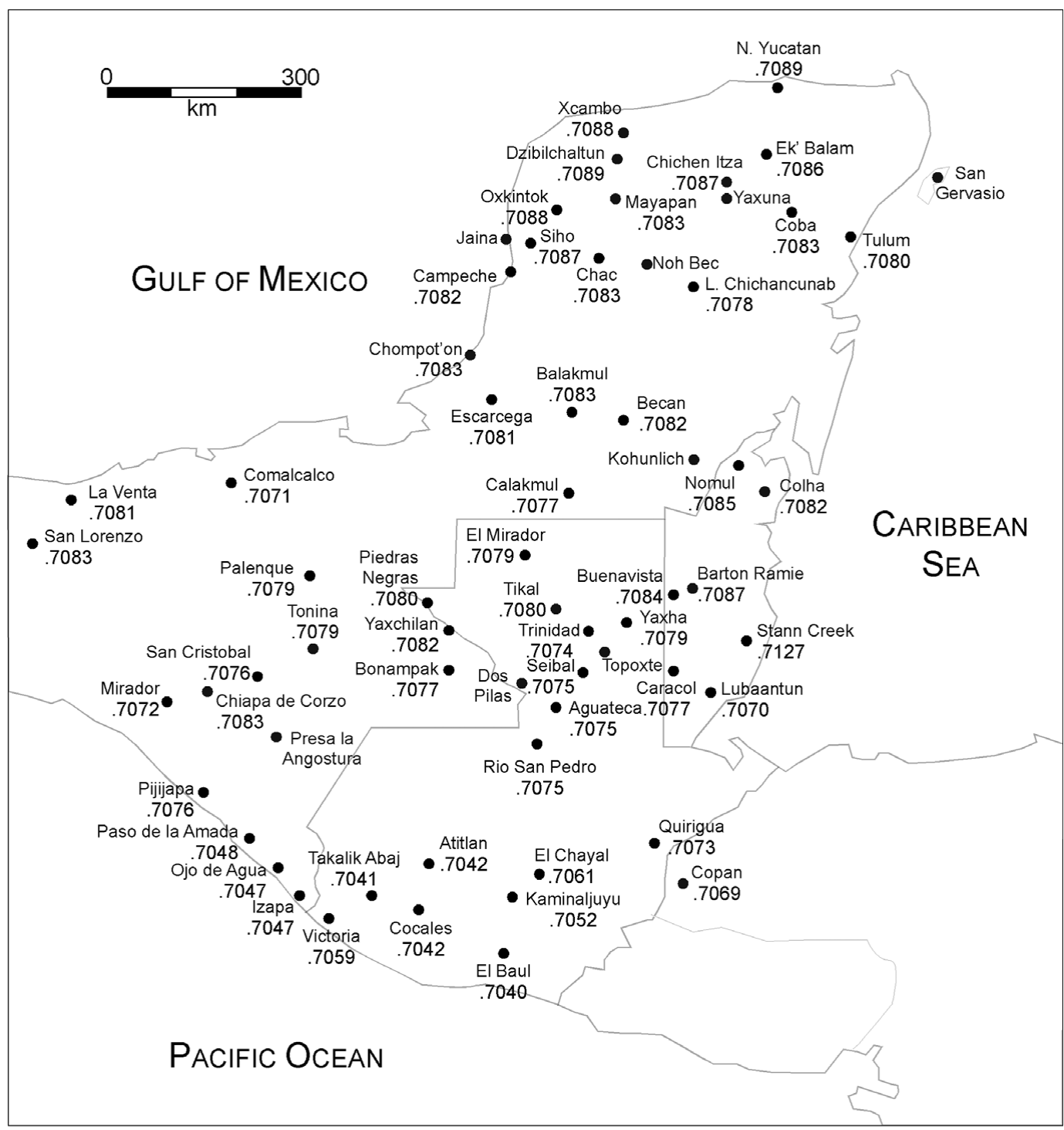

Figure 5. Baseline strontium isotope ratios in the Maya region. Data from Hodell et al. (2004), Krueger (1985), and Price et al. (2008).

Table 3. Strontium Isotope Ratios for Faunal Samples from Calakmul.

\begin{tabular}{llr}
\hline Lab No. & \multicolumn{1}{c}{ Species } & ${ }^{87} \mathrm{Sr} /{ }^{86} \mathrm{Sr}$ \\
\hline F2666 & Odocoileus virginianus & 0.70775 \\
F2667 & Odocoileus virginianus & 0.70775 \\
F3345 & Modern Snail & 0.70775 \\
F3346 & Modern Snail & 0.70777 \\
F3347 & Modern Snail & 0.70780 \\
\hline
\end{tabular}

Burial VII-1, the primary high-status burial in Structure VII, has a much lower $\delta^{13} \mathrm{C}_{\mathrm{col}}$ ratio of $-19.7 \%$, likely indicating more meat in his diet.

Additionally, carbon and nitrogen isotope ratios were measured in collagen from a series of dentine samples for information on adult diet. A number of such light isotope studies have been done in the Maya region for human remains from the Preclassic through Postclassic periods (e.g., Mansell et al. 2006; Tykot 2002; White 1999). The results of these studies generally 


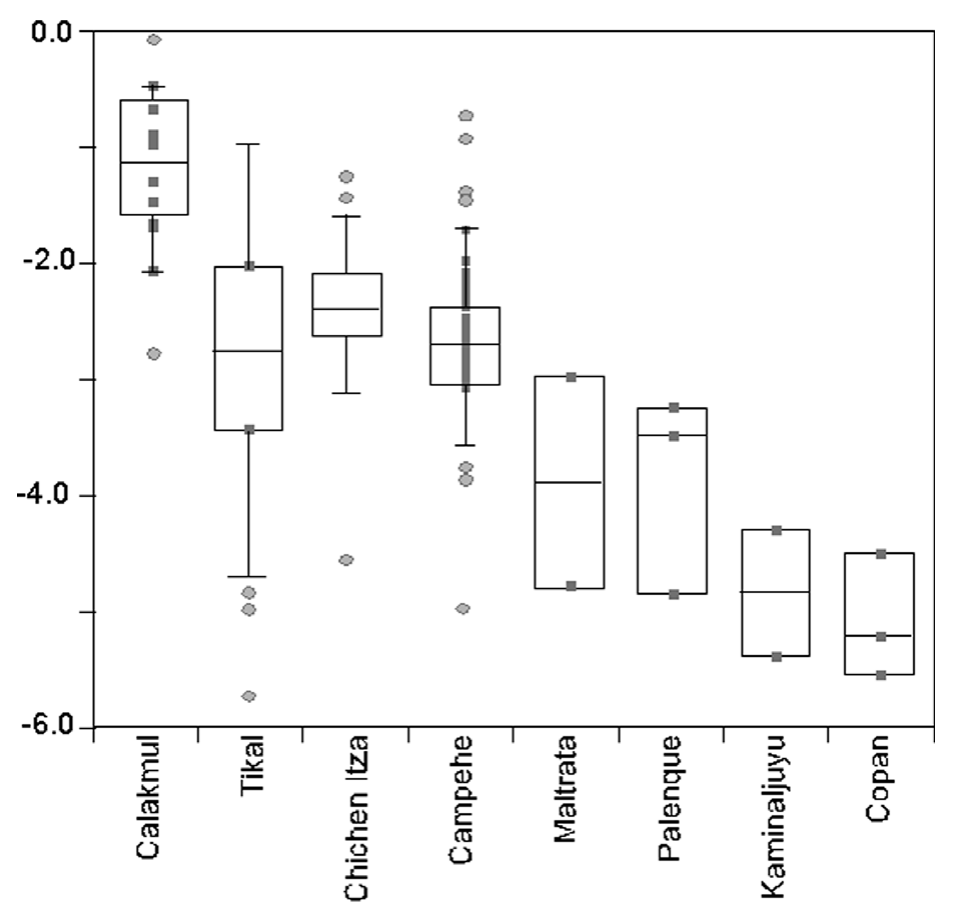

Figure 6. Box and whisker plots of $\delta^{18} \mathrm{O}_{\mathrm{en}}(\mathrm{PDB})$ values from selected Maya sites.

point to diets dominated by maize and to some individual differences in terms of less maize and more protein in elite diets. Both carbon and nitrogen isotope ratios were measured on seven samples from Calakmul (Table 1), with a mean $\delta^{13} C_{a p}$ of $-10.9 \% \pm \pm 2.3$, and range between $-14.5 \%$ and $-7.8 \%$. These values suggest a maize-dominated diet with a good bit of individual variation. The single bone collagen measurement from the radiocarbon sample of Burial VII-1 was significantly different from these eight individuals; he must have had a diet with less maize or other $\mathrm{C} 4$ plants. The eight nitrogen isotope ratios (including one without a carbon companion) average $11.0 \% \pm 1.4$, with a range of 9.2-13.1. These values for carbon and nitrogen isotopes generally fall within the reported range for Maya burials (Price et al. 2012; Tykot 2002). A scatterplot of $\delta^{13} \mathrm{C}$ vs. $\delta^{15} \mathrm{~N}$ for these burials from Calakmul shows some correlation of the carbon and nitrogen isotope ratios, resulting in a negative relationship ( $r=$ $-0.48)$. The value is not significant, but the trend reflects the relationship between consumption of animal protein and maize in the diet — that is, the more animal protein in the diet, the less maize.

\section{Carbon Isotopes in Tooth Enamel}

There are eight samples from Calakmul with apatite carbon measurements. These $\delta^{13} \mathrm{Cap}$ values range from $-8.6 \%$ to $-2.8 \%$ with a mean of $-5.5 \% \pm 2.16$. There is a significant correlation (at 5\%) between the collagen and apatite carbon, $r=0.78$, documenting the relationship between childhood and adult diet among the Maya at Calakmul. The offset between the collagen and apatite $\delta^{13} \mathrm{C}$ values also is of interest. These eight values range between $2.1 \%$ and $6.7 \%$, with a mean of $5.4 \% \pm 1.5$. In general, the offset is greater than $4.4 \%$ and reflects the importance of maize in the diet. There is only one value less than 4.4\%. Burial IIB-2 was excavated in front of the access area to the earthen altar filling the central southern room of Structure IIB (Coyoc Ramírez 2006:56). It has an offset of $2.1 \%$, which suggests that meat protein played a significant role in the diet of this individual. If the 6.9\%o offset of Harrison and Katzenberg (2003) 
is used, all of the ${ }^{13} \mathrm{C}$ apatite-collagen values are below 6.9, pointing to an emphasis on maize in the collagen ${ }^{13} \mathrm{C}$ values.

\section{Oxygen Isotopes in Tooth Enamel}

Oxygen isotope ratios were measured in the enamel apatite of eight individuals from Calakmul. The $\delta^{18} \mathrm{O}$ values ranged from $-0.1 \%$ o to $-2.8 \%$ with a mean of $-1.3 \% \pm 0.8$. These values are the highest recorded in human samples from the Maya region and correlate well with the more positive surface water values reported from this area (Scherer et al. 2015). The two $\delta^{18} \mathrm{O}$ end values in this distribution are $-0.1 \%$ o for Burial $\mathrm{CH} 8-1$ and $-2.8 \%$ for Burial II-6. The values between $0 \%$ and $-2 \%$ are intermediate between those expected from precipitation and consumption of relatively heavy water from aguadas and reservoirs. More specific information on oxygen isotopes in groundwater across Mexico is available from Wassenaar et al. (2009), who report $\delta^{18} \mathrm{O}_{\text {SMOW }}$ values of $-4 \%$ to $-5 \%$ for the entire Yucatan peninsula, slightly lower in the province of Campeche (the location of Calakmul) with values averaging $-3.38 \%$. Lachniet and Patterson (2009) analyzed $\delta^{18} \mathrm{O}$ in surface waters collected from Guatemala and Belize. Values are highest in the area of the central Peten around Calakmul and Tikal, due to evaporation from the lakes. Modern values for surface water in the central and eastern Petén of Guatemala are approximately $+3.0 \%{ }_{\text {sMow }}$, among the highest values in the Maya region. Using the equation $\delta^{18} \mathrm{Oap}(\mathrm{PDB})=0.610 \mathrm{x}$ $\delta^{18} \mathrm{O}(\mathrm{VSMOW})-0.31$, derived from equations of Chenery and others (2012), and correcting for the difference in standards, surface water data correspond to approximately $+1.5 \%$ apatite (PDB) values.

\section{Strontium Isotopes in Tooth Enamel}

Strontium isotope ratios at Calakmul are of interest for a number of reasons. These values from 22 samples range from 0.70778 to 0.70852 , with a mean of $0.7079 \pm 0.0002$. This, rather surprisingly, is the narrowest range of ${ }^{87} \mathrm{Sr} /{ }^{86} \mathrm{Sr}$ values we have recorded at a Maya center. The five faunal samples we measured for baseline bioavailable values also produced a very narrow range, from 0.70775 to 0.70780 . The distribution

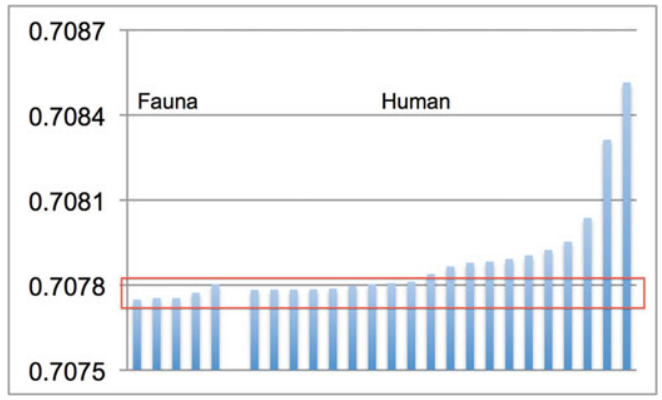

Figure 7. Bar graph of ranked ${ }^{87} \mathrm{Sr} /{ }^{86} \mathrm{Sr}$ for fauna and humans at Calakmul analyzed in this study. (Color online)

of both faunal and human values is presented in a bar graph in Figure 7.

The immediate issue for application of strontium isotope ratios to the burials from Calakmul is the determination of the boundary between local and nonlocal individuals. The very narrow range of values from both the baseline samples and the human remains make this a difficult question. The bar graph in Figure 7 shows three individuals who are distinct from the rest. These individuals are very likely not from Calakmul. The question remains, what about the rest? There is a break in the curve of ranked values in Figure 7 between burials IIH-2 and III-8, that is, at an ${ }^{87} \mathrm{Sr} /{ }^{86} \mathrm{Sr}$ value of 0.70825 .

What does this break in the line of values represent? Is it local versus nonlocal individuals or simply slightly different sources of food? All five of the baseline values from deer and snails fall within the lower range of ratios, suggesting that the values above 0.70925 may be nonlocal. But again, the overall range of values is very narrow, and some variation in the isotope values of the agricultural fields at the huge site is likely. If food was brought to the site from some distance, this might also be reflected in the ${ }^{87} \mathrm{Sr} /{ }^{86} \mathrm{Sr}$ values of some individuals. In sum, because of the narrow range of values within the known range for the Peten, we take a more cautious route and suggest that all of the individuals below 0.708 are local. The three highest ${ }^{87} \mathrm{Sr} /{ }^{86} \mathrm{Sr}$ values in the bar graph (above 0.708) indicate individuals who are different from the rest of the samples, with ratios of $0.7081,0.7083$, and 0.7085 . These higher values, although distinct at Calakmul, also fall within the known range 
for the northern Peten and may not indicate a distant origin. The one individual that stands out dramatically in the plot is the female adult from the Terminal Classic: Burial II-6, found in a midden. There seems little question that Burial II-6 moved from some distance to Calakmul. The low $\delta^{18} \mathrm{O}$ ratio of this individual was noted earlier. The combination of strontium and oxygen ratios indicates a possible place of origin in the Tikal area, perhaps identifying a captive or slave. There was nothing in the grave or location of the burial that would suggest any particular distinction.

\section{Discussion}

Isotopic analyses of a series of 22 samples from the Maya site of Calakmul have provided important information regarding the lives of some of its ancient residential population. They point to the maize-dominated diet and predominantly local origin of the upper crust of this closely knit urban center, some of whom were buried in Structures II, III and VII. In the samples available from the CIHS project, we undertook a variety of measurements including radiocarbon dates, carbon and nitrogen isotope ratios in collagen, and strontium, carbon, and oxygen isotope ratios in tooth enamel. These measurements provide information on date, diet, and place of origin for the individuals analyzed.

\section{Isotopes and Dynastic Life Histories}

Radiocarbon dates were obtained from two bone samples from Calakmul (Table 2). In the case of Burial VII-1, the primary high-status tomb in Structure VII, this date provides a clue regarding the possible identity of its royal occupant. The calibrated BP 2-sigma dates define a range of AD 667-894, a period later than the era of the Snake Kingdom. The golden age of this superpower had come to an abrupt end by thenmore precisely in AD 695, when Calakmul and its royal leader Yich'aak' K'ahk lost a major battle with their old rival Tikal. Theoretically, any of the seven later rulers would fit within this range of radiocarbon years, so this date does not help identify this individual (Marcus 1973; Martin and Grube 2008). Nevertheless, a match with Yuknoom Took' K'awiil seems improbable for reasons of life span. As the inscriptions suggest, Took' K' awiil ruled Calakmul and its hegemony for three decades, from AD 702 to 731 (Martin and Grube 2008). The male adult occupant from the mausoleum in the interior of Structure VII most probably died in his late thirties or forties according to the osteological record (Tiesler et al. 2013), a number of years that appears too few to accommodate three decades of rule (Grube 2005). Presumably local, given the ${ }^{87} \mathrm{Sr} /{ }^{86} \mathrm{Sr}$ value of Burial VII-1, his low $\delta^{13} \mathrm{Ccol}$ ratio points to a distinctive diet. Habitual food intake must have been characterized by a non-C4, nonmarine, terrestrial diet with much more protein, likely meat. Such a menu might be explained by a luxurious lifestyle, given his privileged position in authority and his frequent participation in ostentatious feasting.

\section{Collective Isotopic Dietary Information}

The collagen nitrogen and carbon isotopic ratios confirmed that the diet of the inhabitants of Calakmul was similar to Maya individuals elsewhere-a combination of plant (mostly maize) and animal foods. Average carbon and nitrogen isotope ratios are plotted for a number of Maya sites in Scherer and others (2015:25). Calakmul exhibits the highest $\delta^{15} \mathrm{~N}$ values and a median $\delta^{13} \mathrm{C}$ value compared to other sites. At the same time there is a general similarity among the majority of the sites in terms of overall diet. The higher nitrogen value at Calakmul may be a reflection of the high proportion of elite individuals sampled in this study.

\section{The Residential Histories of Calakmul}

Strontium isotopes provide some information on the place of origin. At Calakmul, a narrow range of values was obtained for the local fauna. The human values are of particular interest in this study because of their narrow range, 0.70778 to 0.70852 . In most cases, this range of values would easily fall into the local range of isotopic variation, and nonlocal individuals would not be discernible. There are three individuals (II2, II-6, and III-1) not from Calakmul, but at the same time likely not from any substantial distance from the site, with the exception of the female Burial II-6 (who may have been a captive or slave). In this case, the combination of 


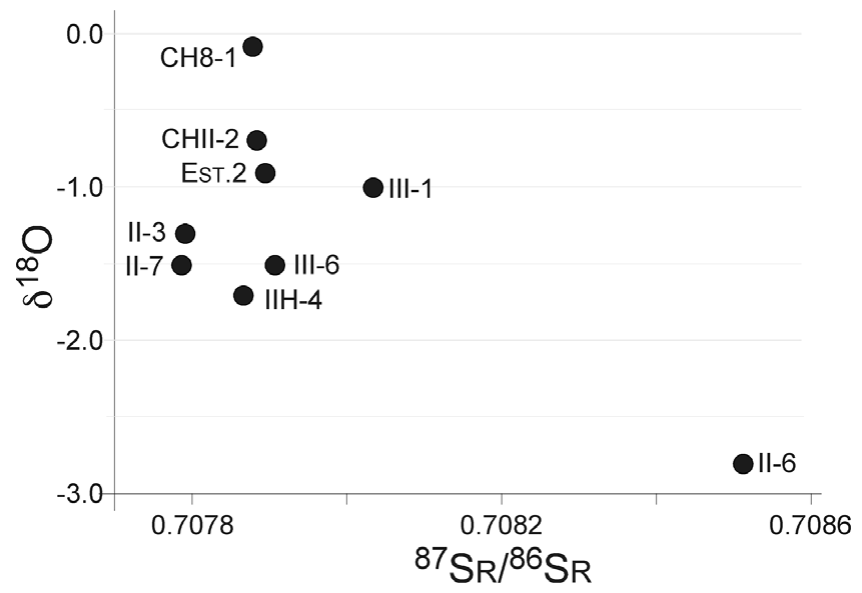

Figure 8. Scatterplot of oxygen and strontium isotope ratios from nine individuals at Calakmul.

strontium and oxygen isotopes point to a person clearly coming from outside the larger region of Calakmul.

Oxygen isotopes provide another perspective on place of origin and are sometimes helpful when combined with strontium data. Figure 8 is a scatterplot of oxygen and strontium isotope ratios from nine individuals at Calakmul. Most of the individuals in this plot fall into a cluster with several pairs (CHII-2 and Est. 2, II-3 and II-7, and III-6 and IIH4). The related burial context of at least one of the pairs (II-3 and II-7) with very similar strontium and oxygen values suggests these individuals may be related or at least grew up in the same or similar households.

Oxygen isotope ratios in enamel contain some information on geographic variation due to differences in precipitation and evaporation in the Maya region. Two individuals, II-6 and $\mathrm{CH}$ 81 , were slightly aberrant in a group of largely similar $\delta^{18} \mathrm{O}$ values. These values are still within the range of variation for a typical population, so the difference may not be meaningful. One question concerns the place of origin for the possible nonlocal individuals identified with strontium isotopes. This question is complicated by the narrow range of ${ }^{87} \mathrm{Sr} /{ }^{86} \mathrm{Sr}$ values at the site and the general lack of variation in $\mathrm{Sr}$ isotope ratios across the northern and central Peten. As noted above, samples from the nearest major centers to Calakmul have average values between 0.708 and 0.709, e.g., Becan 0.7082, Kohunlich 0.7084, El Mirador 0.7090, Tikal 0.7080. It is certain that some of the lower values from these sites overlap with values from Calakmul. Nonlocal individuals at Calakmul, that is, the three highest ${ }^{87} \mathrm{Sr} /{ }^{86} \mathrm{Sr}$ values, could easily be from the region defined by these other centers. At the same time, similar ${ }^{87} \mathrm{Sr} /{ }^{86} \mathrm{Sr}$ values can be found across much of the central Peten, making this area also a potential homeland for the nonlocals at Calakmul. It is very unlikely that these individuals came from the northernmost Maya region where ratios are higher, or the southern part of the Peten or the southern highlands of Guatemala where values are lower.

The isotopic results can be considered in conjunction with the observation of permanent body modification in the form of artificial head shapes and dental decorations among the human remains. Ten sufficiently preserved individuals displayed a morphologically altered head form. Four out of the nine artificially shaped heads showed an artificially reclined frame, and the remaining five showed a broad and short shape, without distinguishing any sex or status correlation, as expected (Tiesler 2014). The only trends that stand out are the lack of inlays among the local royals, one rather late (VII-1) and the other one (III-5) rather early in the dynastic sequence, along with the fact that the foreigners with higher strontium ratios all had tabular erect head shapes, a trend that must have set these newcomers visibly apart from the locals with their diverse head shapes and their mostly reclined foreheads. 


\section{Conclusions}

Used in combination, the isotopes scrutinized in this study provide a powerful means to learn more about the lifestyles and residential histories of the individuals who were buried in the urban core of Calakmul, and to follow broader patterns of population movement, especially given the farreaching long-distance exchange and political networking at Calakmul (Marcus 1973). During its heyday, the Calakmul sphere of influence was far-reaching and stretched from Copan in Honduras to Palenque in Chiapas and Coba in Quintana Roo. The emblem glyph of Calakmul that appears at so many sites within this sphere is associated with the Kaan dynasty (Flannery 1972; Marcus 1973; Velásquez García 2008). The presence of the Kaan glyph at Dzibanche before its use at Calakmul suggests that the dynasty may have had its origins further east towards the Caribbean.

In this light, at first glance the results of this study with mostly local signatures may come as a surprise. The relative absence of clearly defined foreigners in Calakmul stands in contrast to other major Mesoamerican centers for which data are available, such as Teotihuacan (Price et al. 2000), Tikal (Wright 2012), Kaminaljuyu (Wright et al. 2010), and Copan (Price et al. 2010). These populations show a much higher variance for ${ }^{87} \mathrm{Sr} /{ }^{86} \mathrm{Sr}$ values and a much greater proportion of identifiable nonlocal individuals. Based on the large number of samples we have investigated to date, Calakmul seems to have been inhabited primarily by homebodies; that is to say that Calakmul grew over the centuries with a local population. Nonlocal individuals did not settle at Calakmul in large numbers, or at least they do not appear in our sample. The elites born in the region of Calakmul tended to stay there until political breakup, and a major drought during the ninth century led to political meltdown, out-migration, and abandonment of most of the site (Folan 1992a, 1992b; Gunn et al. 1994, 1995). Perhaps the fact that Calakmul was a selfsustaining breadbasket in the Peten made it a better place to be.

On a cautionary note, it is important to remember that the burials used in our study come from the elite core of the site and are not representative of the site as a whole. Given the nature of our sample from Calakmul, it is best to be cautious in concluding statements because the individuals we analyzed lived in the center of the site and were largely members of the elite class. When more individuals from a wider area across the site have been investigated, this picture of a rather closed population may change. For the moment, however, Calakmul seems unusual in terms of the general absence of immigrants and the predominance of local individuals in society.

Investigations such as ours raise more questions than they answer. We regard this study as an initial step in the investigation of biographies of the individuals who inhabited the ancient Maya city of Calakmul, and we look forward to broader coverage in this direction. Beyond the historical particularities of the residential histories, the combination of different datasets holds promise for broadening the frames of explanation of past political processes beyond material products.

Acknowledgments. This study received funding from the National Science Foundation. The radiocarbon measurements were conducted at the Arizona AMS Laboratory, the stable $\mathrm{C}$ and $\mathrm{N}$ isotopes in bone at the Archaeological Science Laboratory of Robert Tycot at the University of South Florida, strontium isotope ratios were measured at the Geochronology and Isotope Geochemistry Lab at the University of North Carolina-Chapel Hill by Paul Fullagar, and carbon and oxygen in enamel apatite were analyzed by David Dettman of the Environmental Isotope Lab at the University of Arizona. Our sincere thanks go to Geoffrey Braswell and anonymous reviewers of earlier drafts of this work.

Data Availability Statement. All of the data used in this study appear in the article itself or have been previously published in cited materials.

\section{References Cited}

Buikstra, Jane E., and Douglas H. Ubelaker (editors) 1994 Standards for Data Collection from Human Skeletal Remains. Arkansas Archaeological Survey Research Series 44. Arkansas Archaeological Survey, Fayetteville.

Carrasco, Ramón

2012 Cronología e Historia. In Calakmul, Patrimonio de la Humanidad, edited by Consuelo Saizar Guerrero, pp. 73-86. Campeche Solidario, Campeche.

Chenery, Carolyn A., Vanessa Pashley, Angela L. Lamb, Hilary J. Sloan, and Jane A. Evans

2012 The Oxygen Isotope Relationship between the Phosphate and Structural Carbonate Fractions of Human Bioapatite. Rapid Communications in Mass Spectrometry 26(3):309-319. 
Coyoc Ramírez, Mario

2006 Prácticas funerarias, élites y contextos problemáticos - extrafunerarios en la estructura II de Calakmul, Campeche. Tesis de Licenciatura en Ciencias Antropológicas en la Especialidad de Arqueología. Facultad de Ciencias Antropológicas, Universidad Autónoma de Yucatán, Mérida.

Domínguez Carrasco

2008 Análisis químico y sociopolítico de producción cerámica prehispánica en la región de Calakmul, Campeche. Colección de Arqueología 5. Universidad Autónoma de Campeche, Campeche.

Domínguez Carrasco, María del Rosario, and William J Folan Higgins

2015 Ceramic Traditions in the Calakmul Region: An Indicator of the Movement of Ideas or Populations? In Archaeology and Bioarchaeology of Population Movement among the Prehispanic Maya, edited by Andrea Cucina, pp.13-24. Springer, New York.

Flannery, Kent V.

1972 The Cultural Evolution of Civilizations. Annual Review of Ecology and Systematics 3:399-426.

Folan, William J.

1992a Calakmul, Campeche: A Centralized Urban Administrative Center in the Northern Petén. World Archaeology 24(1):158-168.

1992b Sacbes y fuentes hidráulicas de los antiguos mayas. In Antropología Mesoamericana. Homenaje a Alfonso Villa Rojas, pp. 335-350. Consejo Estatal de Fomento a la Investigación y Difusión de la Cultura, Gobierno del Estado de Chiapas, Tuxtla Gutiérrez, Mexico.

Folan, William J., and Abel Morales López

1996 Calakmul, Campeche, México: La Estructura II-H, sus entierros y otras funciones ceremoniales y habitacionales. Revista Española de Antropología Americana 26:9-28.

Folan, William J., Joyce Marcus, Sophia Pincemín Deliberos, María del Rosario Domínguez Carrasco, Laraine Fletcher, and Abel Morales López

1995 Calakmul: New Data from an Ancient Maya Capital in Campeche, Mexico. Latin American Antiquity 6:310 334.

Folan, William J., Joel D. Gunn, and María del Rosario Domínguez Carrasco

2001 Triadic Temples, Central Plazas and Dynastic Palaces: A Diachronic Analysis of the Royal Court Complex, Calakmul, Campeche, Mexico. In Royal Courts of the Ancient Maya, edited by Takeshi Inomata and Stephen Houston, pp. 223-265. Westview Press, Boulder, Colorado.

Folan, William J., Laraine A. Fletcher, Jacinto May Hau, Abel Morales López, María del Rosario Domínguez Carrasco, Raymundo Gonzalez Heredia, Joel D. Gunn, and Vera Tiesler

2008 Calakmul, Campeche, México: Patterns Representative of its Urban Capital and Regional State. In El Urbanismo en Mesoamerica, Urbanism in Mesoamerica, edited by Alba Guadalupe Mostache, Robert H. Cobean, Angel Garcia Cook, and Kenneth G. Hirth, pp. 285-347. Pennsylvania State University, Instituto Nacional de Antropología e Historia, Mexico.

Folan, William J., Abel Morales López, Raymundo González Heredia, Maria del Rosario Domínguez Carrasco, A. Anaya Hernández, and Katherine Josserand
2010 El estado regional de Calakmul, Campeche, México: descubrimientos recientes. In La península de Yucatán. Investigaciones recientes y cronologías alternativas, edited by Antonio Benavides Castillo and Ernesto Vargas Pacheco, pp. 59-69. Universidad Autónoma de Campeche, Campeche, Mexico.

Folan, William J., María del Rosario Domínguez Carrasco, Joel D. Gunn, Abel Morales, Raymundo González, Gerardo Villanueva, and Nuria Torrescano

2013 Calakmul: poder, perseverancia y persistencia. In Afinidades biológicas y dinámicas poblacionales entre los antiguos mayas. Una visión multidisciplinaria, edited by Andrea Cucina, pp. 187-212. Ediciones de la Universidad Autónoma de Yucatán, Mérida, Mexico.

García Vierna, Valeria

2004 Máscaras para la vida o para la muerte? Una reflexión sobre la función de las máscaras de mosaico de jadeíta en el área maya. In Culto funerario en la sociedad maya. Memoria de la Cuarta Mesa Redonda de Palenque, edited by Rafael Cobos, pp. 609-626. Instituto Nacional de Antropología e Historia, Mexico. Grube, Nikolai

2005 Ancient Maya Royal Biographies in a Comparative Perspective. In K'inich Janaab' Pakal I of Palenque. Life and Death of a Maya Ruler, edited by Vera Tiesler and Andrea Cucina, pp. 146-166. Arizona University, Tucson.

2008 Monumentos esculpidos: epigrafía e iconografía. In Reconocimiento Arqueológico en el Sureste del Estado de Campeche, México: 1996-2005, edited by Ivan Sprajc, pp. 177-231. BAR International Series 1742. Oxford.

Gunn, Joel D., and William J. Folan

2000 Three Rivers: Subregional Variations in Earth System Impacts in the Southwestern Maya Lowlands (Candelaria, Usumacinta, and Champoton Watersheds). In The Way the Wind Blows: Climate, History, and Human Action, edited by Roderick McIntosh, Joseph Tainter, and Susan K. McIntosh, pp. 263-270. Columbia University, New York.

Gunn, Joel, William J Folan, and Hubert R. Robichaux

1994 Un análisis informativo sobre la descarga del sistema del río Candelaria en Campeche, México: Reflexiones acerca de los paleoclimas que afectaron a los antiguos sistemas mayas en los sitios de Calakmul y el Mirador. In Campeche Maya Colonial, edited by William J. Folan, pp. 174-197. Colección Arqueología. Universidad Autónoma de Campeche, Campeche, Mexico.

1995 A Landscape Analysis of the Candelaria Watershed in Mexico: Insights into Paleoclimates Affecting Upland Horticulture in the Southern Yucatan Peninsula SemiKarst. Geoarchaeology 10(1):3-42.

Harrison, Roman G., and M. Anne Katzenberg

2003 Paleodiet Studies Using Stable Carbon Isotopes from Bone Apatite and Collagen: Examples from Southern Ontario and San Nicolas Island, California. Journal of Anthropological Archaeology 22(3):227244.

Hodell, David A., Rhonda L. Quinn, Mark Brenner, and George Kamenov

2004 Spatial Variation of Strontium Isotopes $\left({ }^{87} \mathrm{Sr} /{ }^{86} \mathrm{Sr}\right)$ in the Maya Region: A Tool for Tracking Ancient Human Migration. Journal of Archaeological Science 31(5):585-601. 
Josserand, J. Katherine

2007 Literatura e historia en los textos jeroglíficos clásicos. Gaceta 93:39-46.

Krueger, Harold W.

$1985 \mathrm{Sr}$ Isotopes and $\mathrm{Sr} / \mathrm{Ca}$ in Bone. Paper presented at Bone Mineralization Conference, Warrenton, Virginia.

Lacadena, Alfonso, and Soeren Wichmann

2002 The Distribution of Lowland Maya Languages in the Classic Period. In La organización social entre los mayas prehispánicos, coloniales y modernos. Memoria de la Tercera Mesa Redonda de Palenque, Vol. 2, edited by Vera Tiesler, Rafael Cobos, and Merle Greene, pp. 275-353. Instituto Nacional de Antropología e Historia, Universidad Autónoma de Yucatán, Mexico.

2005 The Dynamics of Language in the Western Lowland Maya Region. In Art for Archaeology's Sake, Material Culture and Style Across the Disciplines, edited by Andrea Waters-Rist, Christine Cluney, Calla McNamee, and Larry Steinbrenner, pp. 32-48. The University of Calgary, Calgary.

Lachniet, Matthew S., and William P. Patterson

2009 Oxygen Isotope Values of Precipitation and Surface Waters in Northern Central America (Belize and Guatemala) Are Dominated by Temperature and Amount Effects. Earth and Planetary Science Letters 284(3-4):435-446.

Lagunas, Zaid

1985 La exploración de la tumba I de la Zona Arqueológica de Calakmul, Campeche. Información 9:70-98.

Loth, Susan R., and Maciej Henneberg

1996 Mandibular Ramus Flexure: A New Morphologic Indicator of Sexual Dimorphism in the Human Skeleton. American Journal of Physical Anthropology 99(3):473485.

Mansell, Eugenia B., Robert H. Tykot, David A. Freidel, Bruce H. Dahlin, and Traci Ardren

2006 The Importance of Maize to the Yucatan Maya. In Histories of Maize: Multidisciplinary Approaches to the Prehistory, Linguistics, Biogeography, Domestication, and Evolution of Maize, edited by John E. Staller, Robert H. Tykot, and Bruce F. Benz, pp. 173-185. Academic Press, Orlando, Florida.

Marcus, Joyce

1973 Territorial Organization of the Lowland Classic Maya. Science 180:911-916.

1992 Dynamic Cycles of Mesoamerican States. National Geographic Research and Exploration 8 (4):329-411.

2003 Recent Advances in Maya Archaeology. Journal of Archaeological Research 11(2):71-191.

Martin, Simon, and Nikolai Grube

2008 Chronicle of the Maya Kings and Queens. Thames and Hudson, London.

Martínez de Campo Lanz, Sophia

2010 Rostros de la divinidad. Los mosaicos mayas de piedra verde. Instituto Nacional de Antropología e Historia, Mexico.

Medina Martin, Cecilia, and Mirna Sánchez Vargas

2007 Posthumous Body Treatments and Ritual Meaning in the Classic Period Northern Peten. A Taphonomic Approach. In New Perspectives on Human Sacrifice and Ritual Body Treatments in Ancient Maya Society, edited by Vera Tiesler and Andrea Cucina, pp. 102-119. Springer, New York.

Pincemín Deliberos, Sophia

1994 Entierro en el Palacio: La tumba de la Estructura III, Calakmul, Campeche. Universidad Autónoma de Campeche, Colección Arqueología, Campeche.
Price, T. Douglas, Linda Manzanilla, and William D. Middleton

2000 Immigration and the Ancient City of Teotihuacan in Mexico: A Study Using Strontium Isotopes Ratios in Human Bone and Teeth. Journal of Archaeological Science 27(10):903-913.

Price, T. Douglas, James H. Burton, Paul D. Fullagar, Lori E. Wright, Jane E. Buikstra, and Vera Tiesler

$2008{ }^{87} \mathrm{Sr} /{ }^{86} \mathrm{Sr}$ Ratios and the Study of Human Mobility in Ancient Mesoamerica. Latin American Antiquity 19:167-180

Price, T. Douglas, James H. Burton, Robert J. Sharer, Jane E. Buikstra, Lori E. Wright, Loa P. Traxler, and Katherine A. Miller

2010 Kings and Commoners at Copan: Isotopic Evidence for Origins and Movement in the Classic Maya Period. Journal of Anthropological Archaeology 29(1): 15-32.

Price, T. Douglas, James H. Burton, Vera Tiesler, Andrea Cucina, Pilar Zabala, and Robert Tykot

2012 Isotopic Studies of Human Skeletal Remains from a $16^{\text {th }}-17^{\text {th }}$ Century $A D$ Churchyard in Campeche, Mexico: Diet, Ethnicity, Place of Origin, and Age. Current Anthropology 53(4):396433.

Romano, Arturo

1965 Estudio morfológico de la deformación craneana en Tamuín, S.L.P., y en la Isla del Idolo, Veracruz. Serie de Investigaciones 10, Instituto Nacional de Antropología e Historia, Mexico.

Romero, Javier

1958 Mutilaciones dentarias prehispánicas de México y América en general. Instituto Nacional de Antropología e Historia, Mexico.

Scherer, Andrew K., Alyce de Carteret, and Sarah Newman 2015 Local Water Resource Variability and Oxygen Isotopic Reconstructions of Mobility: A Case Study from the Maya Area. Journal of Archaeological Science 2:666-676.

Spence, Michael W., Christine D. White, Fred J. Longstaffe, Evelyn C. Rattray, and Kimberly R. Law

2004 Un análisis de las proporciones de los isótopos de oxígeno en los entierros del Barrio de los Comerciantes. In La costa del Golfo en tiempos teotihuacanos: propuestas y perspectivas. Memoria de la Segunda Mesa Redonda de Teotihuacán, edited by María Elena Ruiz, and Arturo Pascual, pp. 469492. Instituto Nacional de Antropología e Historia, Mexico.

Stuart, George E., and David Stuart

2008 Palenque: Eternal City of the Maya. Thomas and Hudson, London.

Tiesler, Vera

1999 Rasgos bioculturales entre los antiguos mayas: aspectos arqueológicos y sociales. $\mathrm{PhD}$ dissertation, Filosofía y Letras, Universidad Nacional Autónoma de México, Mexico.

2000 Decoraciones dentales entre los antiguos mayas. Ediciones Euroamericanas, Instituto Nacional de Antropología e Historia, Mexico.

2012 Vida y muerte. In Calakmul: patrimonio de la humanidad, edited by Ramón Carrasco, pp. 133-154. Grupo Azabache, Mexico.

2014 The Bioarchaeology of Artificial Cranial Modifications. New Approaches to Head Shaping and its Meanings in Pre-Columbian Mesoamerica and Beyond. Springer, New York. 
Tiesler, Vera, Andrea Cucina, Patricia Quintata Owen, Daniel H Aguilar, Iván Oliva Arias, J.V. Cauich, William J. Folan, and María del Rosario Domínguez Carrasco

2013 What's on the Bone? Interdisciplinary Approaches in Reconstructing the Posthumous Body Treatment of the Ancient Maya Aristocracy of Calakmul, Campache, Mexico. In The Dead Tell Tales. Essays in Honor of Jane E. Buikstra, edited by María Cecilia Lozada, and Barra O'Donnabhain, pp. 85-94. Cotsen Institute of Archaeology Press, University of California, Los Angeles.

Tykot, Robert $\mathrm{H}$.

2002 Contribution of Stable Isotope Analysis to Understanding Dietary Variation among the Maya. In Archaeological Chemistry. Materials, Methods, and Meaning, edited by Kathryn Jakes, pp. 214-230. ACS Symposium Series 831. American Chemical Society, Washington, DC.

Velásquez García, Erik

2008 Los posibles alcances territoriales de la influencia política de Dzibanché durante el Clásico temprano: Nuevas alternativas para interpretar las menciones históricas sobre la entidad política de Kan. In El territorio maya. Memoria de la Quinta Mesa Redonda de Palenque, edited by Rodrigo Liendo, pp. 323-352. Instituto Nacional de Antropología e Historia, Mexico.

Wassenaar, Leonard I., Steven L. Van Wilgenburg, Keith Larson, and Keith A. Hobson

2009 A Groundwater Isoscape $\left(\delta \mathrm{D}, \delta^{18} \mathrm{O}\right)$ for Mexico. Journal of Geochemical Exploration 102:123-136.

White, Christine D. (editor)

1999 Reconstructing Ancient Maya Diet. The University of Utah Press, Salt Lake City.

White, Christine D., Michael W. Spence, Hilary Le Q. StuartWilliams, and Henry P. Schwarcz

1998 Oxygen Isotopes and the Identification of Geographical Origins: The Valley of Oaxaca versus the Valley of Mexico. Journal of Archaeological Science 25(7):643655 .
White, Christine D., Michael W. Spence, Fred J. Longstaffe, and Kimberley R. Law

2000 Testing the Nature of Teotihuacan Imperialism at Kaminaljuyu Using Phosphate Oxygen-Isotope Ratios. Journal of Anthropological Research 56(4):535-558.

White, Christine, David Pendergast, Fred Longstaffe, and Kimberley Law

2001 Social Complexity and Food Systems at Altun Ha, Belize: The Isotopic Evidence. Latin American Antiquity 12:371-393.

White, Christine D., Michael W. Spence, and Fred J. Longstaffe

2002 Geographic Identities of the Sacrificial Victims at the Feathered Serpent Pyramid: Implications for the Nature of State Power. Latin American Antiquity 13:217-236.

2004 Demography and Ethnic Continuity in the Tlailotlacan Enclave of Teotihuacan: The Evidence from Stable Oxygen Isotopes. Journal of Anthropological Archaeology 23(4):385-403.

Wright, Lori E.

2012 Immigration to Tikal, Guatemala: Evidence from Stable Strontium and Oxygen Isotopes. Journal of Anthropological Archaeology 31(3):334-352.

Wright, Lori E., and Henry P. Schwarcz

1998 Stable Carbon and Oxygen Isotopes in Human Tooth Enamel: Identifying Breastfeeding and Weaning in Prehistory. American Journal of Physical Anthropology 106:1-18.

Wright, Juan Antonio Valdéz, James H. Burton, T. Douglas Price, and Henry P. Schwarcz

2010 The Children of Kaminaljuyu: Isotopic Insight into Diet and Long Distance Interaction in Mesoamerica. Journal of Anthropological Archaeology 29(2):155178.

Submitted June 3, 2017; Revised January 2, 2018; Accepted May 17, 2018 